\title{
Organic, organomineral, and mineral fertilizers with urease and nitrification inhibitors for wheat and corn under no-tillage
}

\author{
Juliano Corulli Corrêa(1), Marco André Grohskopf(2), Rodrigo da Silveira Nicoloso(1), \\ Késia Silva Lourenço(3) and Rosemari Martini ${ }^{(1)}$
}

\begin{abstract}
(1)Embrapa Suínos e Aves, BR-153, Km 110, Distrito de Tamanduá, Caixa Postal 321, CEP 89715-899 Concórdia, SC, Brazil. E-mail: juliano.correa@embrapa.br, rodrigo.nicoloso@embrapa.br, rosemari.martini@embrapa.br (2)Universidade Estadual Paulista Júlio de Mesquita Filho, Faculdade de Ciências Agronômicas, Campus de Botucatu, Fazenda Lageado, Rua José Barbosa de Barros, № 1.780, CEP 18610-307 Botucatu, SP, Brazil. E-mail: marcogrohskopf@gmail.com ${ }^{(3)}$ Instituto Agronômico, Avenida Barão de Itapura, no 1.481, CEP 13012-970 Campinas, SP, Brazil. E-mail: slkesia@hotmail.com
\end{abstract}

\begin{abstract}
The objective of this work was to evaluate soil chemical attributes, leaf nitrogen content, and corn and wheat yields under a no-tillage system in response to the application of organic, organomineral, and mineral fertilizers with or without urease and nitrification inhibitors. The experiment was carried out on the field, with one wheat and two corn crops, on a Rhodic Kandiudox, in a randomized complete block design with six replicates. The evaluated treatments were: control, without fertilization; $\mathrm{O}$, poultry litter as an organic fertilizer; $\mathrm{O}+\mathrm{I}$, poultry litter and inhibitors; $\mathrm{OM}$, organomineral fertilizer; $\mathrm{OM}+\mathrm{I}$, organomineral fertilizer and inhibitors; $U$, urea as a mineral fertilizer; and U+I, super urea with the urease inhibitor alone. The use of organic, organomineral, and mineral fertilizers, with or without inhibitors, increased available $\mathrm{N}$ content in the $0.00-0.05-\mathrm{m}$ soil layer. In deeper layers, only $\mathrm{OM}+\mathrm{I}$ in the $0.05-0.10-\mathrm{m}$ layer and $\mathrm{U}+\mathrm{I}$ in the $0.10-0.20-\mathrm{m}$ layer provided higher contents than the control treatment. Leaf $\mathrm{N}$ contents were adequate, regardless of the fertilizer used. The $\mathrm{O}, \mathrm{O}+\mathrm{I}, \mathrm{OM}$, and $\mathrm{OM}+\mathrm{I}$ treatments increase available $\mathrm{P}$ content and base saturation, and decrease $\mathrm{H}+\mathrm{Al}$ on soil surface. Moreover, all fertilizers increase total grain yield of the two studied crops, in the following order: $\mathrm{OM}+\mathrm{I}>\mathrm{U}+\mathrm{I} \geq \mathrm{U}>\mathrm{OM} \geq \mathrm{O}+\mathrm{I} \geq \mathrm{O}$.

Index terms: Triticum aestivum, Zea mays, agronomic efficiency, poultry litter, nitrogen fertilization, volatilization losses.

\section{Fertilizantes orgânicos, organominerais e minerais com inibidores de urease e de nitrificação para trigo e milho em plantio direto}

Resumo - O objetivo deste trabalho foi avaliar os atributos químicos do solo, o teor de nitrogênio foliar e a produtividade de milho e trigo, em sistema plantio direto, em resposta à aplicação de fertilizantes orgânicos, organominerais e minerais, com ou sem inibidores da urease e da nitrificação. $\mathrm{O}$ experimento foi realizado em campo, com um cultivo de trigo e dois de milho, em Nitossolo Vermelho distroférrico, em delineamento de blocos ao acaso, com seis repetições. Os tratamentos avaliados foram: controle, sem adubação; O, fertilizante orgânico de cama de aves; $\mathrm{O}+\mathrm{I}$, cama de aves e inibidores; $\mathrm{OM}$, fertilizante organomineral; $\mathrm{OM}+\mathrm{I}$, fertilizante organomineral e inibidores; $U$, ureia como fertilizante mineral; e $U+I$, superureia com inibidor da urease apenas. $\mathrm{O}$ uso de fertilizantes orgânicos, organominerais e minerais, com ou sem inibidores, aumentou o teor de $\mathrm{N}$ disponível na camada de $0,00-0,05 \mathrm{~m}$ do solo. Nas camadas mais profundas, apenas $\mathrm{OM}+\mathrm{I}$, na camada de $0,05-0,10 \mathrm{~m}$, e $\mathrm{U}+\mathrm{I}$, na de $0,10-0,20 \mathrm{~m}$, proporcionaram maiores teores do que o tratamento-controle. Os teores foliares de $\mathrm{N}$ foram adequados, independentemente do fertilizante utilizado. Os tratamentos $\mathrm{O}, \mathrm{O}+\mathrm{I}$, $\mathrm{OM}$ e $\mathrm{OM}+\mathrm{I}$ aumentam o teor de $\mathrm{P}$ disponível e a saturação por bases, e reduzem $\mathrm{H}+\mathrm{Al}$ na camada superficial do solo. Além disso, todos os fertilizantes aumentam a produtividade total de grãos das duas culturas estudadas, na seguinte ordem: $\mathrm{OM}+\mathrm{I}>\mathrm{U}+\mathrm{I} \geq \mathrm{U}>\mathrm{OM} \geq \mathrm{O}+\mathrm{I} \geq \mathrm{O}$.

Termos para indexação: Triticum aestivum, Zea mays, eficiência agronômica, cama de frango, adubação nitrogenada, perdas por volatilização.

\section{Introduction}

Strategic actions are needed in Brazil to develop technologies that enable the reuse of poultry litter as organic or organomineral fertilizers, since about 5.5 billion broiler poultry were slaughtered in $2015 / 2016$ and there is a growth forecast up to 2020 (Brasil, 2010). Poultry litter is the most widely used organic fertilizer

Pesq. agropec. bras., Brasília, v.51, n.8, p.916-924, ago. 2016

DOI: $10.1590 / \mathrm{S} 0100-204 X 2016000800003$ 
in South Brazil due to its abundance, price, and ease of handling. It is estimated that $16,243,286$ tons of poultry litter are produced annually in the country (Schneider et al., 2012), which can provide numerous benefits to soil physical, chemical, and biological properties if used accordingly to technical criteria (Hirzel et al., 2007; Cassity-Duffey et al., 2015; Mafra et al., 2015).

Using $\mathrm{N}$ fertilizers with urease and nitrification inhibitors could also boost the content of available $\mathrm{N}$ in the soil and, consequently, increase nutrient recovery efficiency by providing a better balance between the $\mathrm{N}$ mineralization and nitrification processes (Muller et al., 2011).

Despite this, few studies have compared the efficiency of organomineral fertilizers with that of mineral ones. Morais \& Gatiboni (2015) found that both types of fertilizer take about 30 days to provide to the plants the $\mathrm{P}$ present in their chemical composition. Other studies have evaluated the association between organic and mineral fertilization in topdressing to increase soil fertility (Cassol et al., 2012). However, researches on technologies using urease and nitrification inhibitors in the formulation of organomineral fertilizers from poultry litter are still scarce.

It should be noted that $\mathrm{N}$ losses by volatilization and leaching decrease $\mathrm{N}$ fertilization efficiency and limit crop yields (Viero et al., 2015). Therefore, urease and nitrification inhibitors may enhance the use efficiency of $\mathrm{N}$ sources during crop fertilization by reducing losses due to ammonia emission $\left(\mathrm{N}^{\left.-\mathrm{NH}_{3}\right)}\right.$ and nitrate leaching $\left(\mathrm{N}^{-\mathrm{NO}_{3}}{ }^{-}\right)$(Zaman et al., 2008; Soares et al., 2012).

In recent studies with inhibitors, urea has been commonly used as a $\mathrm{N}$ source. This technology is responsible for 5 to $10 \%$ of the total $\mathrm{N}$ applied as a fertilizer worldwide (Trenkel, 2010). Among the adopted inhibitors, stand out the molecules of dicyandiamide (DCD), which retard $\mathrm{N}-\mathrm{NO}_{3}{ }^{-}$formation in the soil, and of $\mathrm{N}$-(n-butyl) thiophosphoric triamide (NBPT), which block the active sites of the urease enzyme.

The objective of this work was to evaluate soil chemical attributes, leaf $\mathrm{N}$ content, and corn and wheat yields under no-tillage system in response to the application of organic, organomineral, and mineral fertilizers with or without urease and nitrification inhibitors.

\section{Materials and Methods}

The experiment was carried out on the field, from 2011 to 2013, at the experimental station of Embrapa Suínos e Aves, located in the municipality of Concórdia, in the state of Santa Catarina, Brazil $\left(27^{\circ} 14^{\prime} 2^{\prime \prime} \mathrm{S}, 52^{\circ} 1^{\prime} 40^{\prime \prime} \mathrm{W}\right.$, at $569 \mathrm{~m}$ of altitude). The climate of the region is classified as humid subtropical, $\mathrm{Cfa}$ according to the Köppen-Geiger classification. Monthly data of temperature and rainfall were gathered at the meteorological station of Embrapa Suínos e Aves, about $300 \mathrm{~m}$ from the experimental area (Table 1).

The soil of the experimental area is derived from basalt rocks and is classified as a Nitossolo Vermelho distroférrico (Santos et al., 2013), i.e., a Rhodic Kandiudox. Previous chemical analysis showed the following characteristics in the $0-0.20-\mathrm{m}$ soil layer: $\mathrm{pH}\left(\mathrm{H}_{2} \mathrm{O}\right)$ of $5.0 ; 32.7 \mathrm{~g} \mathrm{dm}^{-3}$ soil organic matter; $1.9 \mathrm{~g}$ $\mathrm{dm}^{-3}$ total $\mathrm{N} ; 60,35,15$, and $40 \mathrm{mmol}_{\mathrm{c}} \mathrm{dm}^{-3} \mathrm{Ca}, \mathrm{Mg}, \mathrm{K}$, and $\mathrm{H}+\mathrm{Al}$, respectively; $35 \mathrm{mg} \mathrm{dm}^{-3} \mathrm{P}$; base saturation of $73 \%$; and soil bulk density of $1.2 \mathrm{~g} \mathrm{~cm}^{-3}$.

The treatments consisted of the application of the following fertilizers, with or without urease and nitrification inhibitors (NBPT and DCD, respectively): $\mathrm{O}$, poultry litter as an organic fertilizer; $\mathrm{O}+\mathrm{I}$, poultry litter and both inhibitors; OM, organomineral fertilizer; $\mathrm{OM}+\mathrm{I}$, organomineral fertilizer and both inhibitors; $\mathrm{U}$, urea as a mineral fertilizer; and $\mathrm{U}+\mathrm{I}$, super urea with the urease inhibitor alone; besides a control, without the application of $\mathrm{N}$ in the soil. The treatments were applied on $35-\mathrm{m}^{2}(5 \times 7 \mathrm{~m})$ plots, with a net area of $15 \mathrm{~m}^{2}$, in which the treatments were arranged in a randomized complete block design with six replicates.

The organic fertilizer used was poultry litter composed of 20, 40, and $22 \mathrm{~g} \mathrm{~kg}^{-1}$ total $\mathrm{N}, \mathrm{P}_{2} \mathrm{O}_{5}$, and $\mathrm{K}_{2} \mathrm{O}$, respectively. The litter was removed from aviary after six rotations. For granulation, poultry litter was micronized and received $0.5 \%$ of cassava starch as a conditioner for aggregation and $0.5 \%$ of calcium silicate to give hardness to the granule, with or without Agrotain Plus (Koch Agronomic Services, LLC, Wichita, KS, USA), which is a product that provides both urease and nitrification inhibitors. This product was used in the proportion of $4 \mathrm{~kg} \mathrm{Mg}^{-1}$ in the poultry litter.

The $\mathrm{N}-\mathrm{P}_{2} \mathrm{O}_{5}-\mathrm{K}_{2} \mathrm{O}$ formulation of the organomineral fertilizer, with or without inhibitors, was 06-16-16. The poultry litter was micronized and added to the diammonium phosphate (DAP) and potassium chloride $(\mathrm{KCl})$ mineral fertilizers in the form of powder, along

Pesq. agropec. bras., Brasília, v.51, n.8, p.916-924, ago. 2016 DOI: 10.1590/S0100-204X2016000800003 
with $0.5 \%$ of cassava starch for aggregation and $0.5 \%$ of calcium silicate for hardness. The proportion of the Agrotain Plus (Koch Agronomic Services, LLC, Wichita, KS, USA) inhibitor added to this formulation was also $4 \mathrm{~kg} \mathrm{Mg}^{-1}$.

Two corn (Zea mays L.) crops were sown in the first half of November, whereas one wheat crop (Triticum aestivum L.) was sown in the second half of May. The sowing of all crops was carried out with a drag-type no-tillage seed drill, with a disk coulter in front of the lagged double disks, with depth-limiter wheels, shank, and V-shaped compactors with two rubber wheels.

In the summer crops with corn, in 2012 and 2013, an early simple hybrid was sown: DKB 240 YieldGard (Monsanto do Brasil Ltda., São Paulo, SP, Brazil), with a cycle of 130 days, a density of 5.8 seeds per meter, and a row spacing of $0.60 \mathrm{~m}$, to obtain a stand of 70,000 plants per hectare. The wheat crop was sown in the winter of 2011 with the cultivar BRS Parrudo - which has an early cycle of 135 days - at a density of 300 to 350 viable seeds per square meter, with row spacing of $0.20 \mathrm{~m}$.

The agronomic efficiency of the different fertilizers was evaluated according to the wheat and corn crop demands to reach high yields. A dose of $100 \mathrm{~kg} \mathrm{ha}^{-1}$ $\mathrm{N}$ was applied to the wheat crop and of $140 \mathrm{~kg} \mathrm{ha}^{-1}$ $\mathrm{N}$ to the corn crops, corresponding, respectively, to 5 and $7 \mathrm{Mg} \mathrm{ha}^{-1}$ of organic fertilizer, 1.7 and $2.3 \mathrm{Mg} \mathrm{ha}^{-1}$ of organomineral fertilizer, and 217 and $304 \mathrm{~kg} \mathrm{ha}^{-1}$ of urea. In addition, for the wheat and corn crops, respectively, the doses of $\mathrm{P}_{2} \mathrm{O}_{5}$ and $\mathrm{K}_{2} \mathrm{O}$ applied with the organomineral fertilizer corresponded to 272 and
$368 \mathrm{~kg} \mathrm{ha}^{-1}$, whereas those with the organic fertilizer were 200 and $280 \mathrm{~kg} \mathrm{ha}^{-1} \mathrm{P}_{2} \mathrm{O}_{5}$ and 110 and $154 \mathrm{~kg} \mathrm{ha}^{-1}$ $\mathrm{K}_{2} \mathrm{O}$. For the mineral fertilizer to provide similar amounts of $\mathrm{P}_{2} \mathrm{O}_{5}$ and $\mathrm{K}_{2} \mathrm{O}$ as those obtained with the organomineral fertilizer, triple superphosphate and potassium chloride were added to the urea.

Organic, organomineral, and mineral fertilizers, with or without inhibitors, were applied to soil surface, next to the planting row, manually and in a single dose, immediately after sowing and without incorporation. The desiccation of weeds was done 14 days before sowing, with manual control during the initial period of plant development.

The stratified soil sampling was performed at the end of the second corn crop, in 2013, when samples were collected at the depths of $0.00-0.05,0.05-0.10$, and $0.10-0.20 \mathrm{~m}$. Three simple samples were taken from the useful area of the plots using a cutting shovel: two from the interrows and one from the row, close to the point sampled in the interrows. The single samples were homogenized to form the composite sample. After collection, the soil was dried in a forced-air circulation oven at $65^{\circ} \mathrm{C}$, milled, sieved in a $2.0-\mathrm{mm}$ mesh sieve, and stored in plastic bags.

In each experimental plot, total $\mathrm{N}$ content, $\mathrm{P}, \mathrm{K}$, $\mathrm{Ca}, \mathrm{Mg}$, and $\mathrm{H}+\mathrm{Al}$ in the soil, as well as total $\mathrm{N}$ in corn and wheat leaves were determined according to the methodologies described by Tedesco et al. (1995). For leaf sampling, 30 leaves were collected from the middle third of the plant, opposite and below the corn spike, in the corn tasseling stage; and 50 flag leaves were collected at the beginning of wheat flowering, as

Table 1. Averages of the maximum and minimum air temperatures and of rainfall during the experimental period, in the municipality of Concórdia, in the state of Santa Catarina, Brazil.

\begin{tabular}{|c|c|c|c|c|c|c|c|c|c|}
\hline \multirow[t]{2}{*}{ Month } & \multicolumn{3}{|c|}{2011} & \multicolumn{3}{|c|}{2012} & \multicolumn{3}{|c|}{2013} \\
\hline & Maximum $\left({ }^{\circ} \mathrm{C}\right)$ & Minimum $\left({ }^{\circ} \mathrm{C}\right)$ & Rainfall (mm) & Maximum $\left({ }^{\circ} \mathrm{C}\right)$ & Minimum $\left({ }^{\circ} \mathrm{C}\right)$ & Rainfall (mm) & Maximum $\left({ }^{\circ} \mathrm{C}\right)$ & Minimum $\left({ }^{\circ} \mathrm{C}\right)$ & Rainfall (mm) \\
\hline January & - & - & - & 30.4 & 19.3 & 176 & 30.6 & 15.9 & 117 \\
\hline February & - & - & - & 31.8 & 21.1 & 161 & 30.0 & 17.3 & 134 \\
\hline March & - & - & - & 29.2 & 17.6 & 74 & 27.0 & 15.5 & 237 \\
\hline April & - & - & - & 25.6 & 15.4 & 136 & - & - & - \\
\hline May & 21.1 & 11.6 & 87 & 24.5 & 11.8 & 46 & - & - & - \\
\hline June & 18.0 & 9.2 & 209 & 21.2 & 9.8 & 153 & - & - & - \\
\hline July & 19.7 & 9.8 & 212 & 19.6 & 9.2 & 212 & - & - & - \\
\hline August & 20.8 & 11.8 & 208 & 24.7 & 13.2 & 0 & - & - & - \\
\hline September & 23.3 & 12.0 & 164 & 25.6 & 13.4 & 110 & - & - & - \\
\hline October & 26.7 & 16.1 & 258 & 25.2 & 16.4 & 246 & - & - & - \\
\hline November & 27.5 & 17.0 & 123 & 31.1 & 16.4 & 39 & - & - & - \\
\hline December & 29.3 & 18.1 & 65 & 31.5 & 18.9 & 159 & - & - & - \\
\hline
\end{tabular}


recommend in the manual of Comissão de Química e Fertilidade do Solo (Tedesco et al., 2004). The leaf samples were placed in paper bags and dried in a forced-air circulation oven at $65^{\circ} \mathrm{C}$, for 72 hours or until achieving constant weight, and then were milled.

In order to estimate grain yield, harvest was carried out manually. For corn, spikes were harvested from the two central rows - with $2 \mathrm{~m}$ length and $0.8 \mathrm{~m}$ width - of the experimental plot, totaling $3.2 \mathrm{~m}^{2}$; and, for wheat, spikes were harvested from the three $0.25-\mathrm{m}^{2}$ micro-plots in each experimental unit. In all crops, grains were manually threshed, weighed, and dried, and grain yield was corrected to $13 \%$ moisture.

The results were subjected to the analysis of homogeneity of variances and normality. There was no need for data transformation. Means were compared by the LSD test, at $5 \%$ probability.

\section{Results and Discussion}

$\mathrm{N}$ content in the $0.00-0.05-\mathrm{m}$ soil layer was higher, when compared with the control, in the treatments that received fertilization with organic, organomineral, and mineral fertilizers, with or without urease and nitrification inhibitors, after the three evaluated crop seasons. However, in the $0.05-0.10-\mathrm{m}$ layer only the $\mathrm{OM}+\mathrm{I}$ treatment differed from the control, and in the $0.10-0.20-\mathrm{m}$ layer, only the U+I treatment was significant (Figure 1). The mineral fertilizers caused greater $\mathrm{N}$ movement in the soil profile than the organomineral ones due to the increased physicochemical solubility of their granules, which provide $\mathrm{N}$ more quickly to soil regardless of the use of inhibitors. It should be pointed out that, although the $\mathrm{OM}+\mathrm{I}$ and $\mathrm{OM}$ treatments did not differ significantly, the first one showed higher values of available $\mathrm{N}$ after two years of cultivation under no-tillage. This result, despite the lack of statistical significance, is an indicative that the presence of inhibitors in the organomineral fertilizer $(\mathrm{OM}+\mathrm{I})$ may reduce $\mathrm{N}$ losses in the soil.

The granulated organic fertilizer $(\mathrm{O}$ and $\mathrm{O}+\mathrm{I})$ provides gradual $\mathrm{N}$ release. When there is an increase in the soil labile organic carbon, biomass and microbial activity are stimulated and may lead to increased $\mathrm{N}$ mineralization efficiency in the soil (Gong et al., 2009). This would explain the absence of significant differences between fertilizers regarding available $\mathrm{N}$
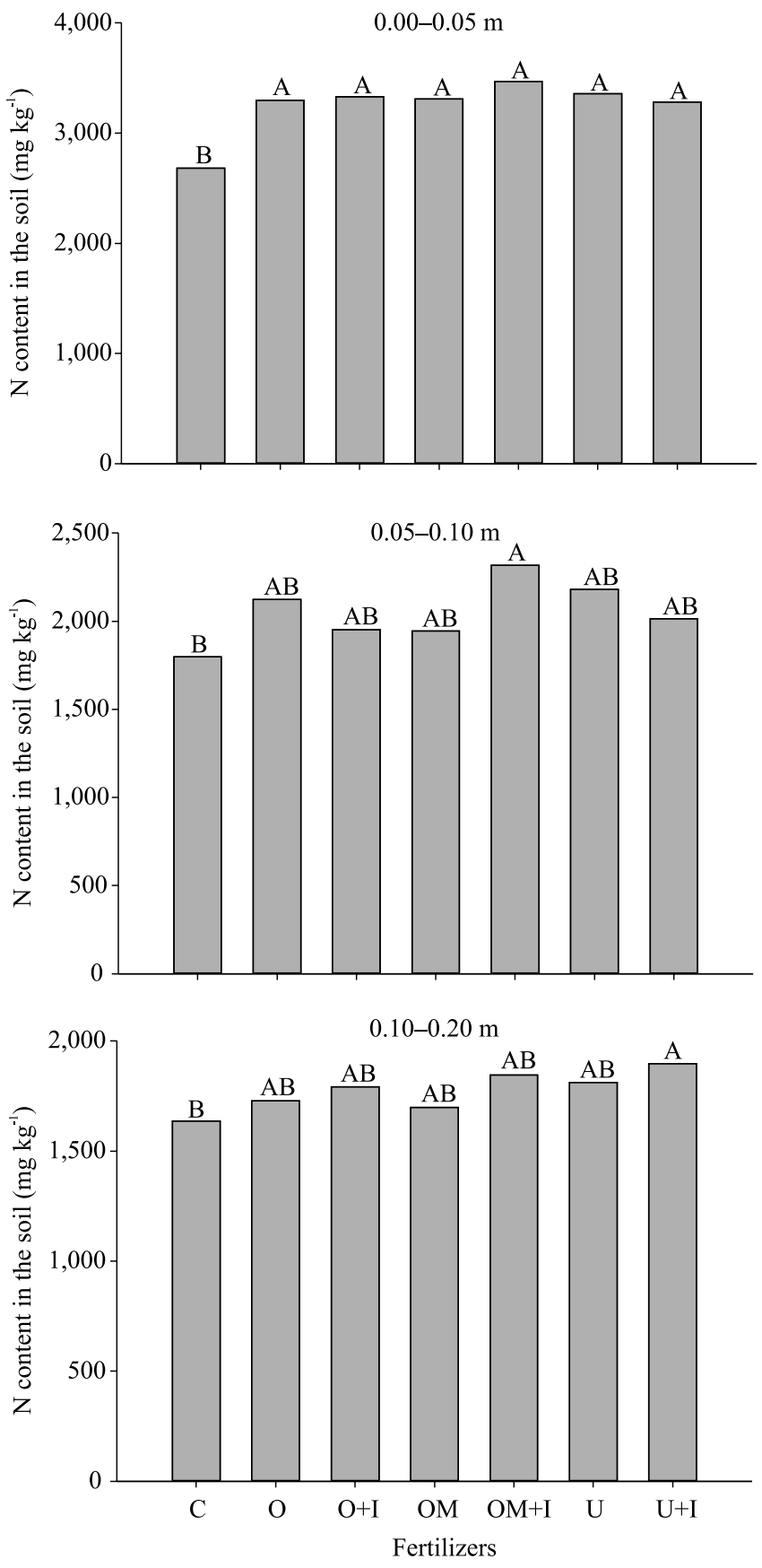

Figure 1. Soil nitrogen content after one wheat (Triticum aestivum) and two corn (Zea mays) crops with the evaluated organic, organomineral, and mineral nitrogen fertilizers, in the $0.00-0.05,0.05-0.10$, and $0.10-0.20-\mathrm{m}$ soil layers. Means followed by equal letters do not differ by the LSD test, at $5 \%$ probability. C, control; O, poultry litter as an organic fertilizer; $\mathrm{O}+\mathrm{I}$, organic fertilizer + urease and nitrification inhibitors; OM, organomineral fertilizer; $\mathrm{OM}+\mathrm{I}$, organomineral fertilizer + urease and nitrification inhibitors; $\mathrm{U}$, urea as a mineral fertilizer; and $\mathrm{U}+\mathrm{I}$, super urea + urease inhibitor. 
contents in the soil. Depending on the type of organic chain in which it is inserted, soil organic $\mathrm{N}$ may have high or low lability (Grohskopf et al., 2015).

The statistical similarity observed between treatments for soil $\mathrm{N}$ availability is related, among other factors, to the buffering power of the cultivation environment given by soil organic matter, in which nutrient contents - classified as medium, but close to high (Tedesco et al., 2004) - may be stabilized in soils at adequate levels for plant growth and production.

After the three crops, the fertilizers provided 393, 264 , and $260 \mathrm{~kg} \mathrm{ha}^{-1} \mathrm{~N}$ in the $0.00-0.05,0.5-0.10$, and $0.10-0.20-\mathrm{m}$ layers, respectively. These values were obtained by the difference between the control and the treatments with $\mathrm{N}$ fertilizers that enabled increased nutrient contents in the soil, such as $\mathrm{OM}+\mathrm{I}$ in the first two layers and U+I in the last one (Figure 1). These results indicate that the production system has provided the stabilization of labile forms of $\mathrm{N}$ in the soil and also that, over the years, new assessments will be needed to guide the decision-making process and to increase the efficiency of $\mathrm{N}$ fertilization.

In the first wheat crop, in 2011, the fertilizers showed similar efficiency regarding the increased leaf $\mathrm{N}$ contents, but only the $\mathrm{O}, \mathrm{O}+\mathrm{I}$, and $\mathrm{U}$ treatments were significantly superior to the control (Figure 2). The $\mathrm{N}$ sufficiency range for the wheat crop is between 20-34 g kg-1 N (Malavolta et al., 1997); therefore, the treatments with fertilizers provided $\mathrm{N}$ contents higher than those recommended by the literature, which evidences that the plants were well supplied with this nutrient.

Still regarding wheat, the efficiency of the organic fertilizers was similar to that of the mineral ones. A possible explanation is the superficial wheat root system, which increases plant capacity to exploit the area of the soil with the highest $\mathrm{N}$ concentration, probably favoring the similar results obtained among fertilizers.

In the second crop season, with corn cultivation in 2012, the treatments differed regarding leaf $\mathrm{N}$ contents; the highest values were observed with the use of soluble mineral sources, especially $\mathrm{U}+\mathrm{I}$ (Figure 2). Considering that the sufficiency range for the corn crop is between 27 and $35 \mathrm{~g} \mathrm{~kg}^{-1} \mathrm{~N}$, only the control and the treatments with organic fertilization $(\mathrm{O}$ and $\mathrm{O}+\mathrm{I}$ ) resulted in lower leaf $\mathrm{N}$ contents than those recommended by the literature.
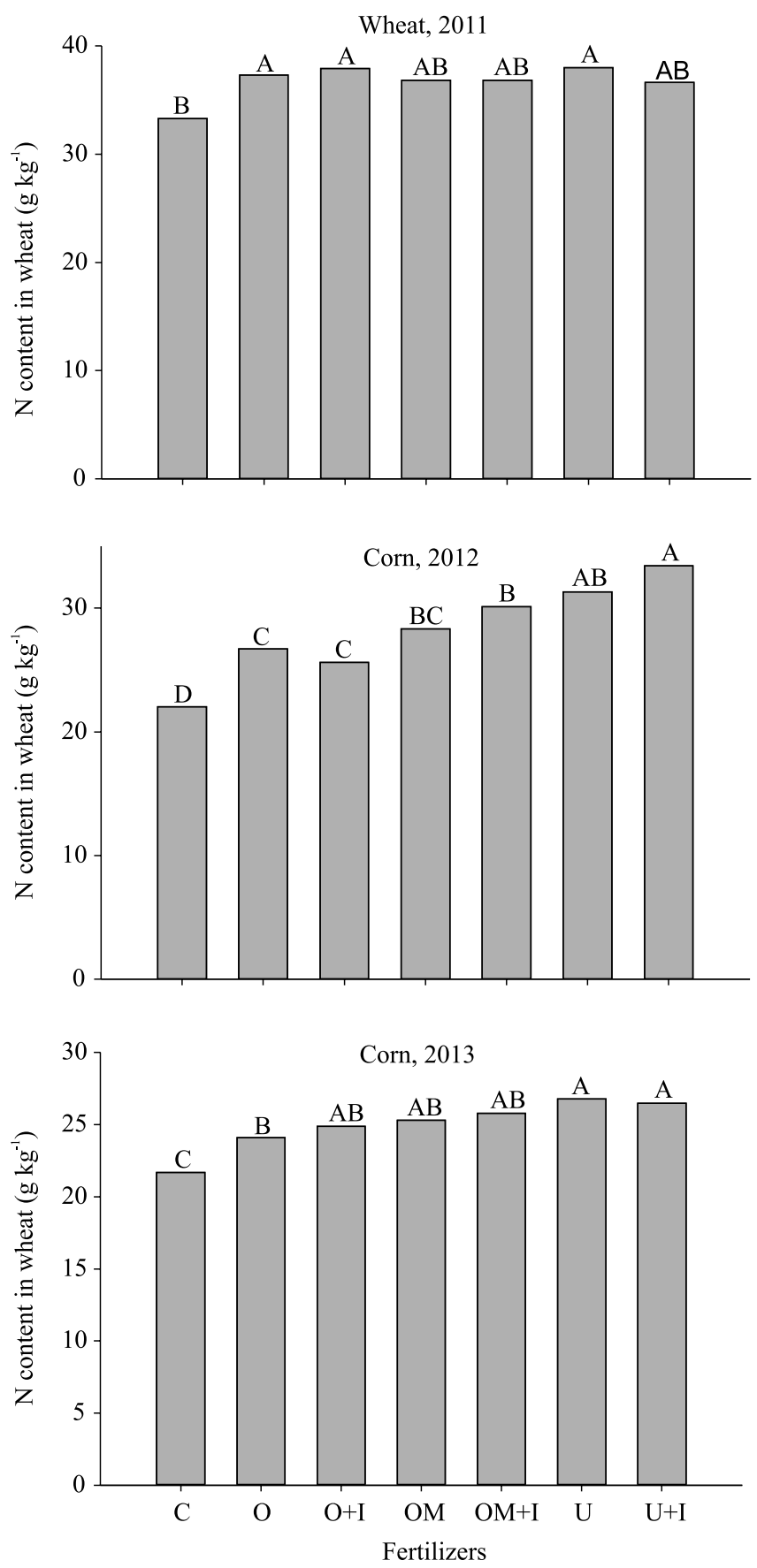

Figure 2. Nitrogen content in wheat (Triticum aestivum) and corn (Zea mays) plants treated with the evaluated organic, organomineral, and mineral nitrogen fertilizers, in 2011, 2012, and 2013. Means followed by equal letters do not differ by the LSD test, at $5 \%$ probability. C, control; O, poultry litter as an organic fertilizer; $\mathrm{O}+\mathrm{I}$, organic fertilizer + urease and nitrification inhibitors; OM, organomineral fertilizer; $\mathrm{OM}+\mathrm{I}$, organomineral fertilizer + urease and nitrification inhibitors; $U$, urea as a mineral fertilizer; and $\mathrm{U}+\mathrm{I}$, super urea + urease inhibitor. 
In the treatments with the same fertilizer, the inclusion of inhibitors did not significantly increase leaf $\mathrm{N}$ content; however, the highest numerical values were found in the treatments with inhibitors. It is interesting to note that the lowest rainfall during the crop cycle (Table 1), in this same crop season, may have contributed to reduce $\mathrm{N}$ losses, which most likely approximated the results of the treatments with and without inhibitors.

In the third crop season, with corn cultivation in 2013, N content in the plant tissue was higher in the treatments with fertilizers (Figure 2). Only the $\mathrm{O}$ treatment presented results lower than those obtained with urea, with or without the presence of the urease inhibitor ( $\mathrm{U}$ and $\mathrm{U}+\mathrm{I}$, respectively); in addition, this was the only treatment, together with the control, in which leaf $\mathrm{N}$ content was below the critical level of $27 \mathrm{~g} \mathrm{~kg}^{-1} \mathrm{~N}$ (Malavolta et al., 1997).

In the 2013 crop season, rainfall was uniform throughout the crop cycle (Table 1), a condition that favors greater nutrient absorption by plant roots.
The organic, organomineral, and mineral fertilizers, with or without inhibitors, caused significant differences in $\mathrm{P}, \mathrm{K}, \mathrm{Ca}, \mathrm{Mg}$, and $\mathrm{H}+\mathrm{Al}$ contents, as well as in base saturation, in different soil layers after two crop years (Table 2). Only the $\mathrm{O}, \mathrm{O}+\mathrm{I}, \mathrm{OM}$, and $\mathrm{OM}+\mathrm{I}$ treatments increased available $\mathrm{P}$ content in the $0.00-0.05$-m layer. It should be highlighted that the presence of organic matter in organic and organomineral fertilizers may reduce $\mathrm{P}$ fixation in crystalline forms of iron and aluminum oxides, since organic matter competes with the anion phosphate for adsorption at these sites (Shuai \& Zinati, 2009).

Although soil K content was classified as very high in the control treatment (Tedesco et al., 2004), it was lower than that obtained with $\mathrm{O}, \mathrm{O}+\mathrm{I}$, and $\mathrm{OM}+\mathrm{I}$ in the $0.05-0.10-\mathrm{m}$ layer, and with $\mathrm{OM}+\mathrm{I}$, U, and $\mathrm{U}+\mathrm{I}$ in the $0.10-0.20$-m layer (Table 2), which shows the effect of the non-restitution of the nutrient on soil fertility. However, when compared with the control, the organic fertilizer decreased $\mathrm{H}+\mathrm{Al}$ contents and

Table 2. Soil chemical properties at different depths after one wheat (Triticum aestivum) and two corn (Zea mays) crops, under the evaluated organic, organomineral, and mineral nitrogen fertilizers ${ }^{(1)}$.

\begin{tabular}{|c|c|c|c|c|c|c|c|c|}
\hline \multirow[t]{2}{*}{ Fertilizer } & $\mathrm{pH}$ & $\mathrm{P}$ & $\mathrm{K}$ & $\mathrm{Ca}$ & $\mathrm{Mg}$ & $\mathrm{H}+\mathrm{Al}$ & $\mathrm{CEC}$ & Base saturation \\
\hline & $\left(\mathrm{H}_{2} \mathrm{O}\right)$ & $\left.(\mathrm{mg} \mathrm{dm})^{-3}\right)$ & ------ & ----- & $\mathrm{mol}_{\mathrm{c}} \mathrm{c}$ & 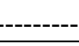 & ----- & $(\%)$ \\
\hline & \multicolumn{8}{|c|}{$0.00-0.05-\mathrm{m}$ soil layer } \\
\hline $\mathrm{C}$ & 5.6 & $19 \mathrm{c}$ & 11.5 & $71 \mathrm{~b}$ & $49 b$ & 39 & 177 & 77 \\
\hline $\mathrm{O}$ & 5.7 & $45 \mathrm{a}$ & 11.9 & $84 a$ & $57 \mathrm{a}$ & 33 & 185 & 82 \\
\hline $\mathrm{O}+\mathrm{I}$ & 5.6 & $41 \mathrm{ab}$ & 14.3 & $81 \mathrm{ab}$ & $57 \mathrm{a}$ & 37 & 188 & 80 \\
\hline $\mathrm{OM}$ & 5.5 & $42 \mathrm{ab}$ & 12.9 & $73 b$ & $53 b$ & 42 & 178 & 77 \\
\hline $\mathrm{OM}+\mathrm{I}$ & 5.5 & $41 \mathrm{ab}$ & 12.2 & $72 b$ & $52 \mathrm{~b}$ & 36 & 172 & 79 \\
\hline $\mathrm{U}$ & 5.5 & $35 \mathrm{~b}$ & 11.5 & $75 b$ & $53 \mathrm{~b}$ & 41 & 181 & 79 \\
\hline \multirow[t]{2}{*}{$\underline{\mathrm{U}+\mathrm{I}}$} & 5.6 & $35 \mathrm{~b}$ & 13.6 & $70 \mathrm{~b}$ & $49 \mathrm{~b}$ & 41 & 177 & 76 \\
\hline & \multicolumn{8}{|c|}{$0.05-0.10-\mathrm{m}$ soil layer } \\
\hline $\mathrm{C}$ & 5.4 & $4.8 \mathrm{~b}$ & $5.9 \mathrm{~b}$ & $55 \mathrm{ab}$ & 37 & $47 \mathrm{a}$ & $145 \mathrm{ab}$ & $67 \mathrm{~b}$ \\
\hline $\mathrm{O}$ & 5.4 & $8.3 \mathrm{a}$ & $9.9 \mathrm{a}$ & $61 \mathrm{a}$ & 38 & $38 b$ & $142 b$ & $76 a$ \\
\hline $\mathrm{O}+\mathrm{I}$ & 5.5 & $10.1 \mathrm{a}$ & $10.8 \mathrm{a}$ & $60 \mathrm{a}$ & 41 & $42 \mathrm{ab}$ & $154 \mathrm{a}$ & $72 \mathrm{ab}$ \\
\hline $\mathrm{OM}$ & 5.3 & $9.5 \mathrm{a}$ & $8.8 \mathrm{ab}$ & $56 \mathrm{ab}$ & 39 & $44 \mathrm{ab}$ & $148 \mathrm{ab}$ & $70 \mathrm{ab}$ \\
\hline $\mathrm{OM}+\mathrm{I}$ & 5.3 & $9.5 \mathrm{a}$ & $10.6 \mathrm{a}$ & $60 \mathrm{a}$ & 40 & $47 \mathrm{a}$ & $158 \mathrm{a}$ & $70 \mathrm{ab}$ \\
\hline $\mathrm{U}$ & 5.3 & $10.0 \mathrm{a}$ & $9.1 \mathrm{ab}$ & $60 \mathrm{a}$ & 39 & $48 \mathrm{a}$ & $156 \mathrm{a}$ & $69 \mathrm{ab}$ \\
\hline \multirow[t]{2}{*}{$\mathrm{U}+\mathrm{I}$} & 5.2 & $9.2 \mathrm{a}$ & $8.2 \mathrm{ab}$ & $50 \mathrm{~b}$ & 35 & $45 \mathrm{ab}$ & $138 \mathrm{~b}$ & $67 \mathrm{~b}$ \\
\hline & \multicolumn{8}{|c|}{$0.10-0.20-\mathrm{m}$ soil layer } \\
\hline $\mathrm{C}$ & 5.4 & 2.5 & $6.0 \mathrm{~b}$ & 47 & 36 & 45 & 134 & 66 \\
\hline $\mathrm{O}$ & 5.4 & 5.0 & $6.9 \mathrm{ab}$ & 55 & 37 & 44 & 142 & 69 \\
\hline $\mathrm{O}+\mathrm{I}$ & 5.3 & 6.0 & $8.3 \mathrm{a}$ & 55 & 35 & 43 & 142 & 70 \\
\hline $\mathrm{OM}$ & 5.4 & 5.5 & $7.8 \mathrm{ab}$ & 57 & 37 & 42 & 144 & 70 \\
\hline $\mathrm{OM}+\mathrm{I}$ & 5.3 & 7.0 & $7.3 \mathrm{ab}$ & 52 & 35 & 42 & 140 & 69 \\
\hline $\mathrm{U}$ & 5.3 & 7.5 & $8.4 \mathrm{a}$ & 54 & 36 & 43 & 139 & 69 \\
\hline $\mathrm{U}+\mathrm{I}$ & 5.3 & 6.0 & $8.5 \mathrm{a}$ & 55 & 38 & 44 & 143 & 70 \\
\hline
\end{tabular}

${ }^{(1)}$ Means followed by equal letters do not differ by the LSD test, at $5 \%$ probability. C, control; $\mathrm{O}$, poultry litter as an organic fertilizer; $\mathrm{O}+\mathrm{I}$, organic fertilizer + urease and nitrification inhibitors; OM, organomineral fertilizer; $\mathrm{OM}+\mathrm{I}$, organomineral fertilizer + urease and nitrification inhibitors; U, urea as a mineral fertilizer; U+I, super urea + urease inhibitor; and CEC, cation exchange capacity. 
increased base saturation; $\mathrm{OM}+\mathrm{I}$ and $\mathrm{U}$ increased $\mathrm{H}+\mathrm{Al}$; and $\mathrm{U}+\mathrm{I}$ increased base saturation in the 0.05 $0.10-\mathrm{m}$ layer. These results may be attributed to the fact that the organic matter present in the organic fertilizer is able to complex aluminum and provide negative charges for the retention of basic cations, when applied in large amounts in the soil-plant system.

Regarding wheat grain yield, only the $\mathrm{OM}+\mathrm{I}$ and $\mathrm{U}$ treatments were superior to the control, and the highest yield was obtained with $\mathrm{OM}+\mathrm{I}$, which presented an increase of $916 \mathrm{~kg} \mathrm{ha}^{-1}$ in comparison with the control (Figure 3). It should be pointed out that, at the beginning of the experiment, the soil already presented $1.25,1.00$, and $1.60 \mathrm{Mg} \mathrm{ha}^{-1} \mathrm{~N}$ in the $0.00-0.05,0.05-$ 0.10 , and $0.10-0.20-\mathrm{m}$ layers, respectively.
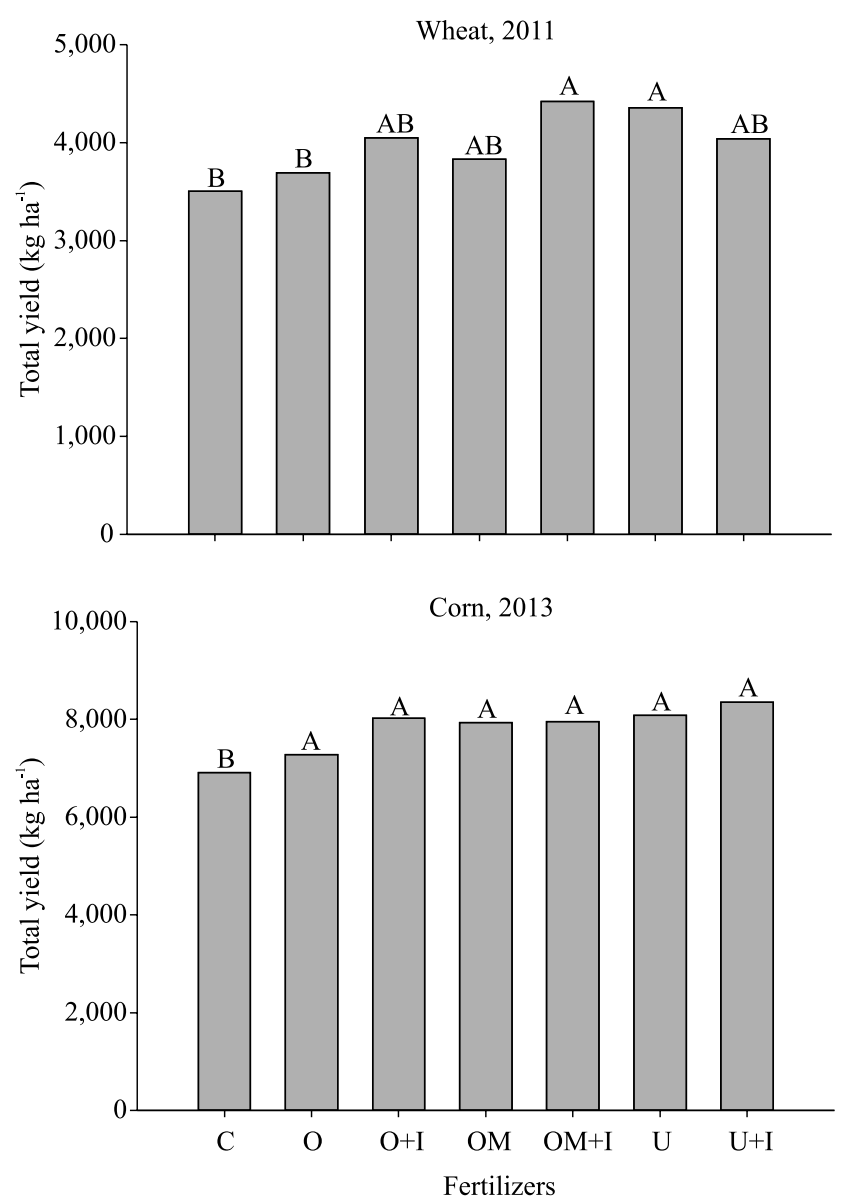

In the 2012 corn crop season, the $\mathrm{OM}+\mathrm{I}$ and $\mathrm{U}+\mathrm{I}$ treatments with inhibitors stood out compared with the other ones (Figure 3). This shows that the slower N release enabled the longer preservation of the nutrient in the soil, with positive effects on yield. In this crop season, the yield gains were of $1,724 \mathrm{~kg} \mathrm{ha}^{-1}$ with the $\mathrm{OM}+\mathrm{I}$ treatment, in comparison with the control.

In the 2013 crop season, with a uniform rainfall distribution, the treatments with fertilizers did not differ from each other, but were superior to the control (Figure 3). However, there was a significant yield gain of $1,656 \mathrm{~kg} \mathrm{ha}^{-1}$ in the $\mathrm{U}+\mathrm{I}$ treatment, when compared with the control.

Even when $\mathrm{N}$ content in the soil was adequate (Figure 2), the contribution of the nutrient to the system allowed gains in the total grain yield of the three crop
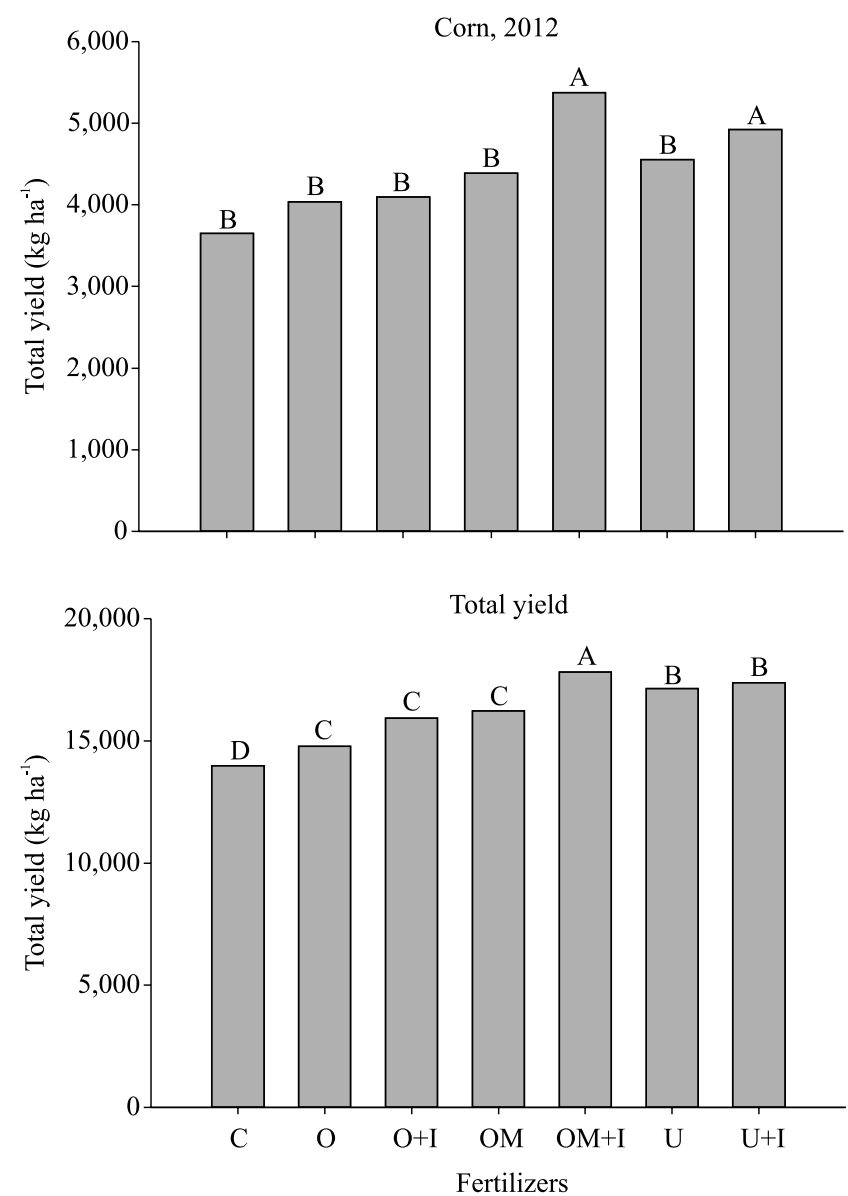

Figure 3. Wheat (Triticum aestivum), corn (Zea mays), and total grain yields after the application of the evaluated organic, organomineral, and mineral nitrogen fertilizers, in 2011, 2012, and 2013. Means followed by equal letters do not differ by the LSD test, at $5 \%$ probability. C, control; O, poultry litter as an organic fertilizer; O+I, organic fertilizer + urease and nitrification inhibitors; OM, organomineral fertilizer; $\mathrm{OM}+\mathrm{I}$, organomineral fertilizer + urease and nitrification inhibitors; $\mathrm{U}$, urea as a mineral fertilizer; and $\mathrm{U}+\mathrm{I}$, super urea + urease inhibitor. 
seasons. During this period, the $\mathrm{OM}+\mathrm{I}$ treatment stood out and was superior to the $\mathrm{U}$ and $\mathrm{U}+\mathrm{I}$ mineral sources, which, in turn, were superior to $\mathrm{OM}, \mathrm{O}+\mathrm{I}$, and $\mathrm{O}$ (Figure 3).

Other studies have shown similar or greater yield with the use of organic fertilizers, such as swine manure or poultry litter, in comparison with that of mineral fertilizer under no-tillage (Cassol et al., 2012). In a Latossolo Vermelho-Amarelo, i.e., a Rhodic Hapludox, with a sandy texture, Fernandes et al. (2007) found no significant differences in coffee (Coffea arabica L.) yield in response to the use of organominerals in solid form and poultry litter-based, when compared with conventional chemical sources. Similarities in crop yield have also been observed between other organic materials and mineral sources in fertilizer formulation (Tejada et al., 2004; Babalola et al., 2007). However, the lack of scientific information and research results does not yet allow the confirmation of the potential and of the risks of using these fertilizers, especially with inhibitors in their formulation.

\section{Conclusions}

1. The use of organic, organomineral, and mineral fertilizers, with or without urease and nitrification inhibitors, increases available $\mathrm{N}$ content in the $0.00-0.05-\mathrm{m}$ soil layer; however, in deeper layers, only the organomineral fertilizer + inhibitors, in the 0.05-0.10-m layer, and super urea + urease inhibitor, in the $0.10-0.20-\mathrm{m}$ layer, are superior to the control.

2 . The used fertilizers increase total grain yield of the evaluated corn (Zea mays) and wheat (Triticum aestivum) crops in the following order: organomineral fertilizer + inhibitors $>$ urea + urease inhibitor $\geq$ urea $>$ organomineral fertilizer $\geq$ organic fertilizer + inhibitors $\geq$ organic fertilizer.

3. The organic fertilizer, organic fertilizer + inhibitors, organomineral fertilizer, and organomineral fertilizer + inhibitors increase available $\mathrm{P}$ content and base saturation, besides decreasing $\mathrm{H}+\mathrm{Al}$ in the soil surface layer.

\section{Acknowledgments}

To Empresa Brasileira de Pesquisa Agropecuária (Embrapa, project No. 01.09.01.001.03.00) and Ferticel Indústria de Fertilizantes, for financial support.

\section{References}

BABALOLA, O.; OSHUNSANYA, S.O.; ARE, K. Effects of vetiver grass (Vetiveria nigritana) strips, vetiver grass mulch and an organomineral fertilizer on soil, water and nutrient losses and maize (Zea mays, L) yields. Soil and Tillage Research, v.96, p.6-18, 2007. DOI: 10.1016/j.still.2007.02.008.

BRASIL. MINISTÉRIO DA AGRICULTURA, PECUÁRIA E ABASTECIMENTO. Projeções do agronegócio: Brasil 2009/2010 a 2019/2020. 2.ed. Brasília: Mapa, ACS, 2010.

CASSITY-DUFFEY, K.; CABRERA, M.; REMA, J. Ammonia volatilization from broiler litter: effect of soil water content and humidity. Soil Science Society of America Journal, v.79, p.543-550, 2015. DOI: 10.2136/sssaj2014.07.0294.

CASSOL, P.C.; COSTA, A.C. da; CIPRANDI, O.; PANDOLFO, C.M.; ERNANI, P.R. Disponibilidade de macronutrientes e rendimento de milho em Latossolo fertilizado com dejeto suíno. Revista Brasileira de Ciência do Solo, v.36, p.1911-1923, 2012. DOI: $10.1590 / \mathrm{S} 0100-06832012000600025$.

FERNANDES, A.L.T.; SANTINATO, R.; DRUMOND, L.C.D.; OLIVERA, C.B.de.Avaliação do uso de fertilizantes organominerais e químicos na fertirrigação do cafeeiro irrigado por gotejamento. Revista Brasileira de Engenharia Agrícola e Ambiental, v.11, p.159-166, 2007. DOI: 10.1590/S1415-43662007000200005.

GONG, W.; YAN, X.; WANG, J.; HU, T.; GONG, Y. Long-term manure and fertilizer effects on soil organic matter fractions and microbes under a wheat-maize cropping system in northern China. Geoderma, v.149, p.318-324, 2009. DOI: 10.1016/j. geoderma.2008.12.010.

GROHSKOPF, M.A.; CASSOL, P.C.; CORREA, J.C.; MAFRA, M.S.H.; PANISSON, J. Organic nitrogen in a Typic Hapludox fertilized with pig slurry. Revista Brasileira de Ciência do Solo, v.39, p.127-139, 2015. DOI: 10.1590/01000683rbcs20150080.

HIRZEL, J.; WALTER, I.; UNDURRAGA, P.; CARTAGENA, M. Residual effects of poultry litter on silage maize (Zea mays L.) growth and soil properties derived from volcanic ash. Soil Science and Plant Nutrition, v.53, p.480-488, 2007. DOI: 10.1111/j.1747 -0765.2007.00144.x.

MAFRA, M.S.H.; CASSOL, P.C.; ALBUQUERQUE, J.A.; GROHSKOPF, M.A.; ANDRADE, A.P.; RAUBER, L.P.; FRIEDERICHS, A. Organic carbon contents and stocks in particle size fractions of a Typic Hapludox fertilized with pig slurry and soluble fertilizer. Revista Brasileira de Ciência do Solo, v.39, p.1161-1171, 2015. DOI: 10.1590/01000683rbcs20140177.

MALAVOLTA, E.; VITTI, G.C.; OLIVEIRA, S.A. de. Avaliação do estado nutricional das plantas: princípios e aplicações. 2.ed. Piracicaba: Potafos, 1997. 319p.

MORAIS, F.A.; GATIBONI, L.C. Phosphorus availability and microbial immobilization in a Nitisol with the application of mineral and organo-mineral fertilizers. Anais da Academia Brasileira de Ciências, v.87, p.2289-2299, 2015. DOI: 10.1590/0001-3765201520140008.

MULLER, C.; LAUGHLIN, R.J.; CHRISTIE, P.; WATSON, C.J. Effects of repeated fertilizer and cattle slurry applications over 38 
years on $\mathrm{N}$ dynamics in a temperate grassland soil. Soil Biology and Biochemistry, v.43, p.1362-1371, 2011. DOI: 10.1016/j. soilbio.2011.03.014.

SANTOS, H.G. dos; JACOMINE, P.K.T.; ANJOS, L.H.C. dos; OLIVEIRA, V.A. de; LUMBRERAS, J.F.; COELHO, M.R.; ALMEIDA, J.A. de; CUNHA, T.J.F.; OLIVEIRA, J.B. de. Sistema brasileiro de classificação de solos. 3.ed. rev. e ampl. Rio de Janeiro: Embrapa, 2013. 353p.

SCHNEIDER, V.E.; PERESIN, D.; TRENTIN, A.C.; BORTOLIN, T.A.; SAMBUICHI, R.H.R. Diagnóstico dos resíduos orgânicos do setor agrossilvopastoril e agroindústrias associadas: relatório de pesquisa. Brasília: Ipea, 2012. 129p.

SHUAI, X.; ZINATI, G. Proton charge and adsorption of humic acid and phosphate on goethite. Soil Science Society of America Journal, v.73, p.2013-2020, 2009. DOI: 10.2136/sssaj2009.0119.

SOARES, J.R.; CANTARELLA, H.; MENEGALE, M.L. de C. Ammonia volatilization losses from surface-applied urea with urease and nitrification inhibitors. Soil Biology and Biochemistry, v.52, p.82-89, 2012. DOI: 10.1016/j.soilbio.2012.04.019.

TEDESCO, M.J.; GIANELLO, C.; ANGHINONI, I.; BISSANI, C.A.; CAMARGO, F.A.O.; WIETHÖLTER, S. (Ed.). Manual de adubação e de calagem para os estados do Rio Grande do Sul e
Santa Catarina. Porto Alegre: Sociedade Brasileira de Ciência do Solo, Núcleo Regional Sul, 2004. 400p.

TEDESCO, M.J.; GIANELLO, C.; BISSANI, C.A.A.; BOHNEN, H.; VOLKWEISS, S.J. Análises de solo, plantas e outros materiais. 2.ed. rev. e ampl. Porto Alegre: UFRGS, 1995. 212p. (UFGRS. Boletim técnico, 5).

TEJADA, M.; BENITEZ, C.; GONZALEZ, J.L. Effects of application of two organomineral fertilizers on nutrient leaching losses and wheat crop. Agronomy Journal, v.97, p.960-967, 2004. DOI: 10.2134/agronj2004.0092.

TRENKEL, M.E. Slow- and controlled-release and stabilized fertilizers: an option for enhancing nutrient use efficiency in agriculture. 2.ed. Paris: International Fertilizer Industry Association, 2010. 160p.

VIERO, F.; BAYER, C.; VIEIRA, R.C.B.; CARNIEL, E. Management of irrigation and nitrogen fertilizers to reduce ammonia volatilization. Revista Brasileira de Ciência do Solo, v.39, p.1737-1743, 2015. DOI: 10.1590/01000683rbcs20150132.

ZAMAN, M.; NGUYEN, M.L.; BLENNERHASSETT, J.D.; QUIN, B.F. Reducing $\mathrm{NH}_{3}, \mathrm{~N}_{2} \mathrm{O}$ and $\mathrm{NO}_{3}{ }^{-}-\mathrm{N}$ losses from a pasture soil with urease or nitrification inhibitors and elemental S-amended nitrogenous fertilizers. Biology and Fertility of Soils, v.44, p.693-705, 2008. DOI: 10.1007/s00374-007-0252-4.

Received on March 30, 2015 and accepted on May 6, 2016 